\title{
Wage-specific Assessment of Mammography Screening in Brazilian Women
}

\author{
Mamografický screening u brazilských žen \\ z hlediska socio-ekonomické stratifikace
}

\author{
Rovere R. K. ${ }^{1}$, Lima A. ${ }^{2}$ \\ 'Oncology Unit, San Antonio Hospital, Blumeau, Santa Catarina, Brazil \\ 2 Private practice, Brusque, Santa Catarina, Brazil
}

\begin{abstract}
Summary
Objective: Mammography is an inexpensive examination that has become a standard screening method thanks to its cost-effectiveness. Due to an enormous cost escalation of cancer treatment over the last years, the assessment of this method, especially in the settings of an emerging country, is a matter of serious concern. Methods: A search within the national health database was conducted registering the data with nation-wide coverage. Data collection and analysis was commenced in 2010 with referrence to the year 2008 as the most recently updated period. The obtained information on mammography screening among Brazilian women was evaluated by subdividing the data in four groups according to socioeconomic status of the subjects. The study population was estimated to comprise about 2 million individuals. Results: More than $45 \%$ of Brazilian women older than 40 years of age have never undergone a mammography. The figures correlated with the income level, reaching an astonishing number of $62.2 \%$ in a group of patients with the lowest income level. Conclusion: Mammography has proved effective in early detection of breast cancer in women. This study suggests that the lack of compliance in breast cancer screening in Brazil, pronounced especially in low-income families, may contribute to the increasing mortality rates associated with the disease.
\end{abstract}

\section{Key words}

mammography - breast cancer - cancer screening

\section{Souhrn}

Cíl: Mamografie je metodou volby v diagnostice časných stadií tumoru prsu díky své efektivitě a relativní finanční nenáročnosti. Vzhledem $\mathrm{k}$ rychlému růstu nákladů na léčbu rakoviny v posledních letech se dostává otázka využití této metody v rozvijejících se zemích do popředí vědeckého zájmu. Metody: Data čerpaná z databáze národního zdravotního systému zahrnují pacienty z celé Brazílie. Sběr dat a a následná analýza proběhla v roce 2010 , s odkazem na rok 2008 , kdy byla zveřejněna poslední aktualizacedatabáze. Údaje o jednotlivých vyšetřeních byly rozděleny do čtyř skupin na základě socio-ekonomických ukazatelů. Celkově soubor zahrnuje asi 2 miliony vyšetření. Výsledky: Více než 45 \% brazilských žen starších 40 let nikdy neabsolvovalo mamografii, přičemž tyto hodnoty korelovaly s výškou průměrné mzdy, a dosahovaly až 62,2 \% u pacientek zařazených do nejnižší socio-ekonomické vrstvy. Závěr: Mamografie je široce využívaná metoda $\mathrm{k}$ záchytu rakoviny prsu $\mathrm{v}$ časných stadiích. Tato studie upozorňuje na skutečnost, že nedostatky v mamografickém screeningovém programu v Brazílii, a neuspokojivá spolupráce pacientek z nižších ekonomických vrstev může přispívat k růstu úmrtnosti spojené s touto diagnózou.

\section{Klíčová slova}

mamografie - rakovina prsu - screening rakoviny
Autoři deklarují, že v souvislosti s předmětem studie nemají žádné komerční zájmy.

The authors declare they have no potential conflicts of interest concerning drugs, products, or services used in the study.

Redakční rada potvrzuje, že rukopis práce splnil ICMJE kritéria pro publikace zasílané do biomedicínských časopisů.

The Editorial Board declares that the manuscript met the ICMJE "uniform requirements" for biomedical papers.

”

Rodrigo Kraft Rovere, MD

Oncology Unit

Santo Antonio Hospital

Rua Itajai 545

Blumenau, Santa Catarina

CEP 89050100 Brazil

e-mail: rodrigorovere@hotmail.com

Submitted/Obdrženo: 14. 10. 2013

Accepted/Přijato: 8. 12. 2013 


\section{Introduction}

Breast cancer in Brazil has shown an increasing trend in mortality, contrary to statistics in most developed countries $[1,2]$. Reasons for that may be less access to drugs still not widely available in the Brazilian national health system with a proven benefit in the adjuvant setting [3], logistic issues such as difficult access to tertiary cancer centres in some states given the continental dimension of the country or poor screening with mammography.

This method has been a subject of many studies in the past years attempting to prove its efficacy in reducing breast cancer related mortality. A meta-analysis published nearly two decades ago reported a $34 \%$ mortality reduction due to mammography screening in a seven-year follow-up period [4].

Initially, the indication for screening mammography was confined to women aged 50 or older, however, later studies set the limits of a target group of women a decade younger. $\mathrm{Cu}$ rrent evidence-based practice recommends to screen women aged 40 to 69 [5-7]. According to Brazilian guidelines the mammography should be performed in all women aged 50 to 69 years in two-year intervals [8]. Still, in the past few years, it has been a common practice to begin the screening in younger patients (from the age of 40 years) [9].
As the cost of cancer treatment is skyrocketing in the past years, is also a matter of utter concern the financial burden that more advanced stages of breast cancer will represent to public resources when considering the prospect of late diagnosis and subsequently more lines of treatment, more hospitalisations and more supportive care medications that these patients will need, given the fact that the mammography is a inexpensive exam proven to be cost effective [10].

\section{Materials and methods}

We searched the most recent update of national health database system from 2008 that encompasses a wide range of patients from all over the country. The data are available on a public domain www. datasus.gov.br. It is estimated to contain more than two million medical records.

The mammography screening programme has been estabilished by the National Institute of Cancer, which administrates the data aquisition and processing. The information on incomes of patients is derived from the annual income tax reports of the Ministry of Economics, provided by the federal government at the website mentioned above.

The patients were subdivided in four groups according to their income class derived from their earnings relative to minimum wage (MW) in the following manner: 0-0.74 MW, 0.75-1.99 MW, equal or more than twice the MW and non-declared income. It is of note, that in January 2012, the Brazilian MW was $\mathrm{R} \$ 622$ (with slight differences depending on a region and type of job), i.e. about $€ 273$.3.

\section{Results}

The investigation revealed alarming results reflecting mammography rates: it has shown that more than $45 \%$ of Brazilian women have never been subjected to mammography whereas the figures correlated negatively with $\mathrm{MW}$, reaching an astonishing number of $62.2 \%$, as demonstrated in the table below.

There was a surprisingly high number of patients who underwent mammography examinations within insufficient time intervals. In the general population the number of these patients approaches $12 \%$.

Similarly, the number of patients never subjected to mammography follows the same pattern and the figures worsen in correspondance with decline in wages.

On the whole, more than $45 \%$ of patients have never undergone mammography, which appears unacceptable in an emerging country.

\section{Discussion}

With regard to the data mentioned above, we can conclude that breast cancer incidence rates in Brazil continue to grow steadily, in contrast to developed countries.

Tab. 1. Distribution of the population according to time of last mammography performed according to per capita wage distribution.

\begin{tabular}{|c|c|c|c|c|c|c|c|c|c|c|}
\hline $\begin{array}{l}\text { Last Mam- } \\
\text { mograpy }\end{array}$ & $\begin{array}{c}0-0.74 \\
\text { MW }\end{array}$ & CI 95\% & $\begin{array}{c}0.75-1.99 \\
M W\end{array}$ & CI 95\% & $\geq 2 \mathrm{MW}$ & Cl 95\% & $\begin{array}{c}\text { Non } \\
\text { declared }\end{array}$ & $\mathrm{Cl} 95 \%$ & Total & $\mathrm{Cl} 95 \%$ \\
\hline total & 100 & $(100-100)$ & 100 & $(100-100)$ & 100 & $(100-100)$ & 100 & $(100-100)$ & 100 & $(100-100)$ \\
\hline $\begin{array}{l}\text { up to one } \\
\text { year }\end{array}$ & 16.16 & $\begin{array}{c}(15.66- \\
16.65)\end{array}$ & 28.58 & $\begin{array}{c}(27.99- \\
29.16)\end{array}$ & 47.20 & $\begin{array}{c}(46.37- \\
48.03)\end{array}$ & 37.99 & $\begin{array}{c}(35.89- \\
40.09)\end{array}$ & 28.45 & $\begin{array}{c}(28.01- \\
28.90)\end{array}$ \\
\hline $1-2$ years & 10.8 & $\begin{array}{c}(10.40- \\
11.20)\end{array}$ & 15.38 & $\begin{array}{c}(14.94- \\
15.82)\end{array}$ & 16.67 & $\begin{array}{c}(16.09- \\
17.25)\end{array}$ & 17.68 & $\begin{array}{c}(16.19- \\
19.16)\end{array}$ & 14.09 & $\begin{array}{c}(13.79- \\
14.79)\end{array}$ \\
\hline $2-3$ years & 4.08 & $(3.84-4.31)$ & 5.07 & $(4.83-5.31)$ & 4.29 & (3.99-4.59) & 3.95 & $(3.25-4.65)$ & 4.50 & $(4.35-4.65)$ \\
\hline$>3$ years & 6.77 & (6.50-7.05) & 8.49 & $(8.17-8.81)$ & 6.54 & (6.19-6.90) & 8.27 & (7.30-9.25) & 7.44 & (7.24-7.64) \\
\hline never did & 62.20 & $\begin{array}{c}(61.45- \\
62.94)\end{array}$ & 42.48 & $\begin{array}{c}(41.83- \\
43.12)\end{array}$ & 25.30 & $\begin{array}{c}(24.60- \\
26.00)\end{array}$ & 32.11 & $\begin{array}{c}(30.14- \\
34.08)\end{array}$ & 45.51 & $\begin{array}{c}(44.98- \\
46.04)\end{array}$ \\
\hline
\end{tabular}

$\mathrm{MW}$ - minimum wage, $\mathrm{Cl}$ - confidence interval $(\mathrm{a}=0.05)$ 
There is an urgent need of a new governmental policy in the promotion of screening programs among women over 40 years of age, targeting especially low income families, as it is obviously a prevalent subgroup in Brazilian population and also the most neglected in terms of health care and mammographic screening as demonstrated above.

\section{References}

1. Silva GA, Gamarra CJ, Girianelli VR et al. Cancer mortality trends in Brazilian state capitals and other municipa- lities between 1980 and 2006. Rev Saude Publica 2011 45(6): 1009-1018.

2. Siegel R, Ward E, Brawley O et al. Cancer statistics, 2011 the impact of eliminating socioeconomic and racial disparities on premature cancer deaths. CA Cancer J Clin 2011; 61(4): 212-236

3. Piccart-Gebhart MJ, Procter M, Leyland-Jones B et al. Trastuzumab after adjuvant chemotherapy in HER2-positive breast cancer. N Engl J Med 2005; 353(16): 1659-1672. 4. Elwood M, Cox B, Richardson A. The effectiveness of breast cancer screening by mammography in younger women: correction. Online J Curr Clin Trials 1994; 121: 385.

5. Nyström L, Andersson I, Bjurstam N et al. Long-term effects of mammography screening: updated overview of the Swedish randomised trials. Lancet 2002; 359(9310): 909-919.
6. Freedman DA, Petitti DB, Robins JM. On the efficacy of screening for breast cancer. Int J Epidemiol 2004; 33(1): 43-55. 7. Gøtzsche PC, Nielsen M. Screening for breast cancer with mammography. Cochrane Database Syst Rev 2006; 4: CD001877

8. Caetano S, Junior JM, Finguerman F et al. Mammographic assessment of a geographically defined population at a mastology referral hospital in Sao Paulo Brazil. PLoS One 2013; 8(9): e74270.

9. Silva TB, Mauad EC, Carvalho AL et al. Difficulties in implementing an organized screening program for breast cancer in Brazil with emphasis on diagnostic methods. Rural Remote Health 2013; 13(2): 2321.

10. Ginsberg GM, Lauer JA, Zelle $S$ et al. Cost effectiveness of strategies to combat breast, cervical, and colorectal cancer in sub-Saharan Africa and South East Asia: mathematical modelling study. BMJ 2012; 344: e614. 